\title{
25 Research Soure \\ The Effects of 2,2',4'-Trihydroxychalcone on the Cell Proliferation, Metastasis, and Apoptosis in Human Lung Cancer Cell Line A549
}

Jialin Sun

The Affiliated Hospital of Qingdao University

Zhanqi Cao

The Affiliated Hospital of Qingdao University

Shiwei Sun

Qingdao University

Zhonghua Sun

The Affiliated Hospital of Qingdao University

Shuhong Sun

The Affiliated Hospital of Qingdao University

Jinfeng Ye

Ocean University of China

Ping Leng ( $\nabla$ 18661808926@163.com )

The Affiliated Hospital of Qingdao University https://orcid.org/0000-0002-0881-1954

\section{Research}

Keywords: Flavonoids, 2,2',4'-trihydroxychalcone, lung cancer, proliferation, migration

Posted Date: September 3rd, 2021

DOl: https://doi.org/10.21203/rs.3.rs-859926/v1

License: (9) This work is licensed under a Creative Commons Attribution 4.0 International License.

Read Full License 


\section{Abstract}

Objectives $₫$ Our study aimed to evaluate the antitumor effects of 2,2',4'-trihydroxychalcone (7a) on human lung cancer cell line A549.

Methods $₫ A 549$ cells were treated with different concentrations of $7 a$ for different times. The cells without $7 a$ were set as the negative control group. The cell proliferation, invasion, vasculogenic mimicry (VM) formation, heterogeneous adhesion, apoptosis were, respectively, measured by CCK-8, transwell invasion assay, vasculogenic mimicry assay, adhesion assay and flow cytometry. In addition, the expression of related proteins were examined via western blot or ELISA.

Results冈Our research found that 7a had a significant inhibitory effect on the survival rate of lung cancer A549 cells, while almost had no effect on human lung epithelial BEAS-2B cells and human venous endothelial cells (HUVECs). The migration rate, VM length, invasion and heterogeneous adhesion number of cells treated with 7a significantly decreased as the increase in concentration, while the apoptosis rate increased. Western blot analysis showed that 7a treatment significantly upregulated the expression of Ecadherin, cleaved PARP, Bax, caspase-3, and simultaneously downregulated the expression of MMP-2/9, Bcl-2, p-PI3K, p-Akt, p-MTOR, VEGF, E-selectin and N-cadherin. At the same time, ELISA results found that the pro-angiogenic factor VEGF level in culture media was reduced in the presence of $7 \mathrm{a}$. Additionally, $7 \mathrm{a}$ could also reduce the nucleus NF-KB protein level, which would inhibit gene transcription of tumor activity-related proteins.

Conclusion 87 a might exert inhibitory effects on A549 cells via inhibiting cell proliferation, migration, VM formation, heterogeneous adhesion and inducing apoptosis through suppressing the PI3K/AKT/NF-KB signaling pathway, suggesting that $7 \mathrm{a}$ might have therapeutic potential for the treatment of lung cancer.

\section{Background}

Lung cancer can be divided into small cell lung cancer (SCLC) and non-small cell lung cancer (NSCLC), of which $85 \%$ are non-small cell lung cancer and further divided into three major pathological subtypes: adenocarcinoma, squamous cell carcinoma and large cell carcinoma [1]. Lung cancer is one of the most common malignant tumors in the world, which is a serious threat to human health and life. Lung cancer not only has high morbidity and mortality, but also has a poor prognosis, with a five-year survival rate of less than 15\%. Each year, 1.8 million people are diagnosed with lung cancer and 1.6 million die [2]. Early lung cancer is mainly treated by surgery, chemotherapy, and radiotherapy, and advanced lung cancer can be treated by molecular targeted therapy and immunotherapy. However, the five-year survival rate is still very low, and the malignant metastasis rate of lung cancer is as high as $93 \%$ [3]. Therefore, adopting multitarget combination therapy, combining chemotherapy with chemobiologic therapy or exploring new target drugs is a new choice for lung cancer treatment.

Flavonoids are widely distributed in plants in nature and have extensive pharmacological activities, such as liver protection, antioxidant effects and antitumor effects, etc. For example, isoliquiritigenin (ISL), a 
flavonoid extracted from licorice, has been confirmed to exhibit antitumor, anti-inflammatory and antioxidant capabilities in vitro and vivo [4-6]. Additionally, ISL was also shown to induce quinone reductase (QR) activity, which could promote cancer chemoprevention [7]. ISL inhibits many tumor activities, such as tumor proliferation, metastasis, apoptosis, etc. In recent years, various antitumor mechanisms of ISL have been detailedly elucidated. For example, in endometrial cancer cells, ISL could induce cell cycle arrest in the G1 or G2/M phase through the p53/p21 pathway and promote apoptosis and autophagy through activation of the extracellular signal-regulated kinase pathway. In addition, ISL was also reported to induce cell apoptosis and inhibit proliferation through the PI3K/AKT signaling pathway [8]. 2,2',4'-trihydroxychalcone (7a) belongs to flavonoids and is an isomer of isoglycyrrhizin $\left(4,2^{\prime}, 4^{\prime}\right.$-trihydroxychalcone, ISL) (Fig. 1). The only difference is a hydroxyl is substituted in a different place on the benzene ring. Therefore, 7a may also exhibit similar antitumor effects as ISL. In our research, we firstly examined the effects of 7 a on cell proliferation, migration, invasion, VM formation, heterogeneous adhesion and apoptosis in human lung cancer cell line A549. And at the same time, 7a almost had no effect on the proliferation of human lung epithelial cells BEAS-2B and human venous endothelial cells (HUVECs), suggesting that 7a had low cytotoxicity to normal cells. Additionally, 7a could downregulate the expression of N-cadherin, VEGF and MMP-2/9, while upregulated the expression of Ecadherin, Bax, caspase-3 and Bcl-2 in A549 cells. Simultaneously, 7a significantly inhibited the of $\mathrm{PI3K} / \mathrm{AKT} / \mathrm{NF}-\mathrm{KB}$ signaling pathway in A549 cells. Therefore, 7a may be a potential compound for the treatment of lung cancer.

\section{Materials And Methods}

\section{Materials}

RPMI-1640 medium, DMEM medium, fetal bovine serum (FBS) and L-glutamine were purchased from GIBCO BRL (Grand Island, NY, USA). Monoclonal antibodies against PI3K, p-PI3K, P-Akt, Akt, Caspase-3, Bax, MMP-9, GADPH, $\beta$-catenin, E-cadherin, $N$-cadherin and $\beta$-actin were from CST (Boston, MA, USA). 7a and ISL were provided by the Natural Medicinal Chemistry Laboratory of Qingdao University. ECL reagent was from Beyotime (Shanghai, China). Subcellular structure of cytoplasm and cell nucleoprotein extracted kit was from Boster Biological Technology (Wuhan, China). Cell counting kit-8 (CCK8), Bovine serum albumin (BSA), Vybrant DiO Cell labelling Solutions, RIPA lysis buffer and PMSF were purchased from Solarbio (Beijing, China). Culture dish, 6-well plates, 24-well plates and 24-well Transwell chambers with 8.0-Im polycarbonated filters was from Corning (NY, USA). Matrigel was from BD (Franklin, USA). Annexin V-fluorescein isothiocyanate (FITC) apoptosis detection kit was from beyotime (Beinjing, China).

\section{Cell lines}

Human lung cancer cells A549, human lung epithelial cell BEAS-2B and human vascular umbilical vein endothelial cells (HUVECs) were obtained from the Shanghai Culture Collection of Chinese Academy of Sciences. A549 and BEAS-2B cells were cultured in RPMI 1640 medium containing 10\% FBS. HUVECs 
were cultured in DMEM medium containing $10 \%$ fetal bovine serum. All media were supplemented with $100 \mathrm{U} / \mathrm{mL}$ streptomycin/penicillin. All cells were cultured in an incubator at $37^{\circ} \mathrm{C}$ with $5 \% \mathrm{CO}_{2}$.

\section{Cell proliferation assay}

$100 \mu \mathrm{L}$ cell suspension $\left(1 \times 10^{3}\right.$ cells/well) was inoculated in a $96-$ well plate. The plates were pre-cultured in an incubator for 24 hours (at $37^{\circ} \mathrm{C}, 5 \% \mathrm{CO}_{2}$ ). $10 \mu \mathrm{L}$ of different concentrations of 7 a to be tested were added to the culture plate and incubated in the incubator for $24 \mathrm{~h}, 48 \mathrm{~h}$ and $72 \mathrm{~h}$. Added $10 \mu \mathrm{L} \mathrm{CCK}-8$ solution to each well. Incubate the plates in the incubator for 1-4 hours. The absorbance at $450 \mathrm{~nm}$ was measured with a microplate analyzer. Based on OD value results, a curve was drawn for the analysis of cell proliferation inhibition analysis. The results were analyzed from three independent experiments.

\section{Wound-healing assay}

The procedure of wound-healing assay was performed in 6-well plates according to Liang [9]. A549 cells were harvested and seeded on 6-well plates at a density of $4 \times 10^{5}$ cells in $2 \mathrm{ml}$ of complete RPMI 1640 and incubated at $37^{\circ} \mathrm{C}$ for $24 \mathrm{~h}$. A straight line was scraped on the monolayer cells with $200 \mu$ pipette tip. Different concentrations of 7A solution were added to the cells and incubated in 1640 medium without FBS. The scratch photographs were then captured by utilizing Leica DFC420 camera under an inverted microscope at $0 \mathrm{~h}, 18 \mathrm{~h}$ and $36 \mathrm{~h}$, respectively. The gap width was analyzed along the scratch with a scale plate in the microscope. At least 6 points are measured for each scratch. The results were analyzed from three independent experiments.

\section{Cell invasion assay}

An invasion assay was performed using 24-well Transwell chambers coated with Matrigel (1:15 dilution in serum-free RPMI 1640 medium ). A549 cells were harvested and suspended by different concentrations of 7asolution in serum-free RPMI 1640 medium at a density of $1 \times 10^{6}$. Then 50ul suspended cells were seeded in the upper chamber of each well, and the bottom chamber was filled with 600 ul RPMI 1640 medium supplemented with $10 \%$ FBS. After incubated at $37^{\circ} \mathrm{C}$ for $24 \mathrm{~h}$, cells that didn't traversed the matrigel were rubbed off by using cotton swab. After washed by PBS, cells that traversed the matrigel were immobilized by paraformaldehyde (4\%) for $20 \mathrm{~min}$ and stained by crystal violet for $30 \mathrm{~min}$. After washed by PBS, cells that penetrated the matrigel were counted in ten randomly chosen fields using an inverted microscope with a 20 objective (200 magnifications).

Formula:

Invasion inhibition ratio $(\%)=(1-$ cells that traversed the matrigel $) \times 100 \%$ 


\section{Vasculogenic mimicry assay}

First, Matrigel matrix glue stored at $-20^{\circ} \mathrm{C}$ was transferred to $4^{\circ} \mathrm{C}$ for overnight melting.The 5OPL matrix was added to a 96 -well plate with a $-20^{\circ} \mathrm{C}$ precold gun and placed in a $37^{\circ} \mathrm{C}$ cell incubator for incubation for $1 \mathrm{~h}$ before solidification. Add $50 \mu \mathrm{L}$ A549 cell suspension ( $5 \times 10^{4} /$ well) and $50 \mu \mathrm{L}$ different concentrations of drug-containing medium. And, at the same time the solvent control group was set up. Then, the cells were incubated in the cell incubator for $8 \mathrm{~h}$, and the formation of tubules was observed under a microscope and photographed. The tubule branch length was counted using Image J.

\section{ELISA assay}

A549 cells were collected and inoculated into 24 -well plates ( $5 \times 10^{4} /$ well). After the cells were attached to the wall, the original medium was discarded and drug-containing media of different concentrations $7 \mathrm{a}$ were added. Meanwhile, the NC group was set up and continued to be incubated in a $37^{\circ} \mathrm{C}, 5 \% \mathrm{CO}_{2}$ cell incubator for $24 \mathrm{~h}$. Then the supernate was transferred to the centrifugal tube for $1000 \mathrm{r} / \mathrm{min}$ centrifugal, 5 min. The supernate was transferred to a new centrifugal tube again. According to the instruction of VEGF ELISA kit, the VEGF levels in each group were tested.

\section{Cancer cell-endothelial adhesion assay}

Cancer cell-endothelial adhesion was performed as described by early research [10]. A549 cells was cultured in 6-well plates with different concentrations of 7a and HUVECs was cultured in 24-well plates. After incubated at $37^{\circ} \mathrm{C}$ for $48 \mathrm{~h}$, A549 cells were washed with PBS and labeled with $5 \mathrm{uM}$ DIO fluorescent cell labeling solution in serum-free RPMI 1640 medium for 30 min at $37^{\circ} \mathrm{C}$. Next step, tumor cells were washed with PBS and then released from the culture plates. A549 cells were collected by centrifuging at $500 \mathrm{~g}$ for $3 \mathrm{~min}$. After washing, $5 \times 10^{4}$ cells were applicated for $1 \mathrm{~h}$ at $37^{\circ} \mathrm{C}$ to the HUVECs monolayer cultured in 24-well plates. Next step, the 24-well plates were gently washed with PBS and the fluorescentlabeled cells were counted in ten randomly chosen fields using an Olympus B51 fluorescent microscope with 10 objective (100 magnifications).

\section{Analysis of cell apoptosis}

A549 cells either treated with with different concentrations of $7 \mathrm{a}$ or $0.1 \% \mathrm{DMSO}$ for $48 \mathrm{~h}$ at $37^{\circ} \mathrm{C}$. Cell suspension (about $10 \times 10^{4}$ ) was collected and centrifuged at $1000 \mathrm{~g}$ for $5 \mathrm{~min}$. The supernatant was discarded and the cells were gently resuspend with $195 \mu \mathrm{L}$ Annexin V-FITC binding solution. $5 \mu \mathrm{L}$ Annexin V-FITC was added in cells and mixed gently. $10 \mu \mathrm{L}$ propidium iodide staining solution was added and mixed gently. Incubate in dark for $10-20$ minutes at room temperature $\left(20-25^{\circ} \mathrm{C}\right)$, then place in an ice bath. Then the apoptotic cells were detected by flow cytometry according to instruction of the apoptosis detection kit. Annexin V-FITC fluorescence was green and propidium iodide (PI) fluorescence was red. The 
flow cytometry results were analyzed via flow software. The results were analyzed from three independent experiments

\section{Western blot analysis}

A549 cells were seeded in 6 -well plates $\left(2 \times 10^{5}\right.$ cells per well). $24 \mathrm{~h}$ later, cells were treated with different concentrations of $7 \mathrm{a}$. After incubated at $37^{\circ} \mathrm{C}$ for $48 \mathrm{~h}$, cell lysates were collected in RIPA lysis buffer PMSF (99:1, v/v) and centrifuged at $14000 \mathrm{r} / \mathrm{min}$ for $15 \mathrm{~min}$. Then the total protein concentrations were determined using the Pierce BCA Protein Assay Kit (Thermo Fisher, USA). Adequate buffer (6x) was added to the total protein and mixed completely. The mixture was then heated at $100^{\circ} \mathrm{C}$ for $5 \mathrm{~min}$. Next step, 15 30ug total proteins were fractionated on 10\% sodium dodecyl sulfate-polyacrylamide gel electrophoresis (SDS-PAGE) and transferred to polyvinylidenefluoride (PVDF) membranes (Millipore, Billerica, MD, USA). The membranes were incubated with primary antibodies after blocking with $5 \%$ nonfat milk. The primary antibodies used were anti-PI3K, anti-Akt, anti-N-cadherin and anti- $\beta$-actin antibodies, etc. According to the sources of different primary antibodies, the membranes were incubated with the corresponding secondary antibodies, and then laid on the developer board of the gel image processing instrument. ECL developer was added to avoid light drops to detect the exposure of the strips. Image Lab software was used for band processing and analysis, and $\beta$-actin was used as an internal reference for semiquantitative analysis of protein expression in each group.

\section{Statistical analysis}

The above experiments were repeated for three times. SPSS software was used for statistical analysis of all data, and the experimental results were expressed as mean $\pm S D$. The difference between the groups was analyzed by t-test. ${ }^{*} \mathrm{P}<0.05$ indicated statistical difference between the groups, and ${ }^{*} \mathrm{P}<0.01$ indicated significant statistical difference between the groups.

\section{Results}

\section{7a inhibits A549 proliferation}

The inhibitory effect of $7 a$ on the proliferation of A549 cells was measured by using CCK-8. A549 cells were treated with different concentrations of $7 \mathrm{~A}$ for 24,48 , and $72 \mathrm{~h}$. The viability of A549 cells was determined, and the growth curves of A549 cells were drawn. As shown in Figure 2, 7a could inhibit the proliferation and growth of A549 in a time-dose-dependent manner. The IC50 value of 7a against A549 cells was calculated according to Figure 2A. The results showed that the IC50 of 7a on A549 cell growth was $65.72 \pm 4.20,33.46 \pm 4.11$ and $19.86 \pm 2.33 \mu \mathrm{M}$ at 24,48 and $72 \mathrm{~h}$, respectively. These results indicated that 7a could inhibit the proliferation of A549 cells at higher concentration and longer time. 
On the other hand, we examined the toxic effects of $7 \mathrm{a}$ on two types of normal human tissue cells. We selected normal human lung epithelial cell BEAS-2B and human venous endothelial cell HUVEC. CCK-8 test results showed that $7 \mathrm{a}$ had no significant proliferation inhibition effect on these two kinds of cells. Among them, although HUVECs were relatively sensitive to $7 \mathrm{a}$, the maximum proliferation inhibition rate was less than $20 \%$ at $40 \mu \mathrm{M}, 72 \mathrm{~h}$. These results indicated that $7 \mathrm{a}$ had a selective killing effect on tumor cells, but had no obvious toxic and side effects on normal cells, so it had a good potential for clinical application.

\section{7a inhibits A549 cell migration and invasion}

According to the results of CCK-8 experiment, we selected 2.5 and $5 \mu \mathrm{M}$ as the non-cytotoxic concentration as the drug concentration in the invasion and metastasis experiment. Firstly, we tested the effect of $7 \mathrm{a}$ on the migration ability of A549 cells by cell scratch assay, and the results showed that 7a could significantly inhibit the migration ability of A549 cells. The migration inhibition rate was decreased from $43.61 \%$ to $21.30 \%$ and $17.52 \%$ at $18 \mathrm{~h}$, and from $61.50 \%$ to $31.22 \%$ and $22.10 \%$ at $36 \mathrm{~h}$ (Figure $3 \mathrm{~A}$ ). On the other hand, we also examined the effect of $7 \mathrm{a}$ on the invasion ability of A549 cells by transwell invasion assay. Compared with the NC group, the number of A549 cells passing through the compartment was reduced in the 7 a group at $48 \mathrm{~h}$, especially the high concentration $(5 \mu \mathrm{M})$ group (Figure $3 \mathrm{~B}$ ). These results demonstrated that 7a could markedly inhibit the migration and invasion of A549 cells at non-cytotoxic concentration.

To understand the mechanism of $7 \mathrm{a}$ inhibiting the migration and invasion of A549 cells, we further detected the expression of cell metastasis-related proteins. As shown in Figure 3C, 7a could significantly increase the expression of E-cadherin, while at the same time decrease the expression of metalloproteinase-9 (MM-9) and metalloproteinase-2 (MMP-2), suggesting that the inhibition of migration and invasion by $7 \mathrm{a}$ might be due to the regulation of the expression of these proteins.

\section{7a inhibits vasculogenic mimicry}

Highly invasive tumor cells, such as non-small cell lung cancer, can form mimicry vessels, that is, tumor cells show some characteristics similar to vascular endothelial cells and can degrade the basement membrane to connect to form a network structure $[11,12]$. Therefore, in vitro mimicry angiogenesis experiments, we used matrigel to simulate the basement membrane and observed the simulated angiogenesis of tumor cells in each group. The experimental results are shown in Figure 4A. In the NC group, A549 cells were connected to each other to form multiple grid structures. However, in the 7a dosing group, the branch length of mimetic vessels was significantly reduced, especially after treatment with $10 \mu \mathrm{M} 7 \mathrm{a}$ for $8 \mathrm{~h}$, the cells were dispersed and almost no tubules were formed, and the inhibition rate of mimetic vessel formation was as high as $82.89 \%$. These results indicated that 7 a could significantly inhibit the formation of mimicry vessels in A549 cells in a concentration-dependent manner.

As a pro-angiogenic factor, vascular endothelial growth factor (VEGF) not only plays an important role in angiogenesis, but also has been reported to be related to tumor cells [13]. Western blot and ELISA were 
used to detect the effect of 7a on the expression and secretion of VEGF in A549 cells and culture media. As shown in Figure 4B, 7a inhibited the expression of VEGF in A549 cells compared with the NC group. Next step, ELISA results (Figure 4C) showed that A549 cells were treated with different concentrations of $7 \mathrm{a}$ for $24 \mathrm{~h}$, and VEGF secretion was significantly reduced in a concentration-dependent manner. The results suggested that 7 a could significantly inhibit the expression and secretion of VEGF in 549 cells.

\section{7a inhibits A549 cells adhesion to HUVECs}

Heterogeneous adhesion of tumor cells is a pivotal step in tumor metastasis. A549 cells treated with different concentrations of 7a were stained with DIO dye and then added to 24-well plates that covered with a single layer of HUVECs, which could mimic the adhesion of tumor cells to the lining of blood vessels. We examined the adhesion of A549 cells to HUVECs by incubation with different concentrations of $7 \mathrm{a}$ for $48 \mathrm{~h}$. The fluorescent cells above the HUVECs monolayer are adhered A549 cells. The results showed that $2.5,5,10 \mu \mathrm{M} 7 \mathrm{a}$ significantly reduced $\mathrm{A} 549$ cells adhesion to HUVECs by $3.12 \%, 13.8 \%$, and $34.4 \%$, respectively (Figure $5 \mathrm{~A}$ ). The results suggested that 7a could inhibit the adhesion of A549 cells to HUVECs in a concentration-dependent manner.

Next step, we explored the molecular mechanism by which 7a regulates the adhesion of A549 cells to vascular endothelial cells. The relevant adhesion protein levels were detected by western blot analysis. As showed in Figure 5B, the expression of $\mathrm{N}$-cadherin and E-selectin were significantly reduced following treatment with different concentrations of $7 \mathrm{a}$. These two adhesion molecules have been proved to involve in adhesion between tumor cells and HUVECs $[10,14]$. The adhesion could then promote tumor cell aggregation in the blood vessels, which could avoid anoikis and increase tumor metastasis potential. Therefore, 7a may inhibit A549 cell metastasis by inhibiting the expression of $\mathrm{N}$-cadherin and E-selectin.

7 a promotes $A 549$ cells apoptosis. The effects of different concentrations of 7a on apoptosis of A549 cells were quantitatively determined by Annexin V-FITC/PI double staining. The normal living cells, early apoptotic cells, necrotic cell and late apoptotic cells could be distinguished by flow cytometry. As shown in Figure 6A, the apoptosis rate of A549 cells in NC group was 5.4\%. The total apoptosis rate of A549 cells increased to $9.6 \%, 16 \%$, and $28.2 \%$ after treatment with 5,10 , and $20 \mu \mathrm{M} 7 \mathrm{a}$ for $48 \mathrm{~h}$. To further explore the mechanism of 7a inducing apoptosis in A549 cells, the effect of 7a on the expression of mitochondrial apoptosis-related proteins was detected by western blot. As shown in Figure 6B, the expression levels of proapoptotic proteins Bcl-2, Bax, cleavated PARP, and Caspase-3 were significantly increased, while the expression of antiapoptotic protein Bcl-2 was significantly decreased. This result indicated that the promotion of apoptosis of A549 cells by 7a might be related to the mitochondrial apoptosis pathway.

\section{7a inhibits the activation of the PI3K/AKT signaling pathway}

A variety of biological processes in a variety of tumor cells are regulated by the PI3K/Akt signaling pathway, including cell proliferation, apoptosis, survival, growth, and movement. Akt and mTOR proteins have been reported to serve an important role in tumor cell viability and metastasis [15]. In the present 
study, we detected the relevant proteins in PI3K/AKT signaling pathway by utilizing western blot analysis. As shown in Figure 7A, the phosphorylation levels of PI3K, Akt, and mTOR in the 7a dosing group were significantly decreased, and the expression levels of their downstream proteins NF-kB were decreased. Additionally, we further separately examined the NF-KB level in the cytoplasm and nucleus. As showed in Figure 7B, NF-KB level in the cytoplasm of 7a dosing group were slightly decreased, while NF-KB level in the nucleus was markedly decreased compared to NC group. These results demonstrated that 7a may inhibit the PI3K/AKT/NF-KB signaling pathway.

\section{Discussion}

Distant metastasis and easy recurrence are the leading cause of lung cancer death. And the morbidity of brain metastases is increasing worldwide. Traditional chemotherapy drugs have the characteristics of easy tolerance and many serious adverse reactions, which has become a difficulty in the treatment of lung cancer. In recent years, although various targeted drugs have been applied, the global five-year survival rate is still very low. Hydroxy chalcone compounds have been found to have anti-inflammatory, antimicrobial, antioxidant, anticancer activity, immunomodulatory, liver and heart protection and many other pharmacological activities. Many researchers have payed attention to their antitumor effects. For example, reports have shown that ISL can inhibit the proliferation and induce apoptosis of lung adenocarcinoma cell line $\mathrm{A} 549$ and $\mathrm{NCl}-\mathrm{H} 1975[8,16]$. However, according to the results of previous studies, the antitumor activity of isoglycyrrhizin is relatively weak. Therefore, more effective hydroxy chalcone compounds are needed to be explored, and understanding the antitumor mechanisms of these compounds may help explore new lung cancer treatments. Our study firstly tried to investigate the antitumor effect of 7a on the biological behaviors of NSCLC cells. In the present study, 7a was demonstrated to significantly inhibit the proliferation, migration, invasion, and heterogeneous adhesion of A549 cell and induce cell apoptosis, indicating that 7a may have an anticancer effect on the growth and metastasis of A549 cells. Firstly, we studied the effect of 7a on the proliferation of A549 cells and found that 7a exhibited a stronger inhibition of the growth of A549 cells. 7a significantly inhibited the migration and invasion by upregulating the expression of E-cadherin and downregulating the expression of $\mathrm{N}$ cadherin in A549 cells. Both E-cadherin and N-cadherin are markers of epithelial-mesenchymal transition (EMT), which is a pivotal mechanism involved in the modulation of cell migration and invasion. However, in the process of EMT, their expression regulation is opposite, E-cadherin expression is downregulated, while N-cadherin expression is often upregulated [17]. The decreased expression of E-cadherin leads to the loss of E-cadherin-mediated isotype adhesion between epithelial cells, driving the higher metastatic potential of tumor cells [11]. In addition, MMP-2 and MMP-9 expression were also decreased slightly in the presence of 7a. MMPs have proteolytic properties, can degrade the extracellular matrix, and participate in various biological processes, especially the invasion and metastasis of tumors. During the process of invasion and metastasis, tumor cells first bind to the basement membrane and then release MMPs, which degrades the basement membrane and extracellular matrix, and finally enables tumor cells to move to the periphery along the damaged site, thus causing invasion and metastasis $[18,19]$. Among the MMPs, MMP-2 and MMP-9 play a crucial role in tumor invasion and metastasis. MMP-2, also known 
as gelatinase A, mainly degrades elastic fibers and types IV, V, VII, and X collagen. MMP-9, namely gelatinase B, not only degrades the matrix of cells, promotes the invasion and metastasis of tumor cells, but also participates in the occurrence and development of tumors by promoting the formation of capillaries [19]. Thus, the results of the present study suggest that 7a may suppress the migration and invasion of A549 cells through inhibiting the process of EMT and decreasing the expression of MMP-2/9.

What' more, tumor heterogeneous adhesion is also a pivotal step in cancer hematogenous metastasis. Cellular adhesion molecules (CAMs) are transmembrane proteins located on the cell membrane and are the major regulators of this process, regulating cell-cell or extracellular matrix (ECM) interactions. It was reported that cell surface adhesion molecules, such as N-cadherin, CD44, and E-selectin, could promote adhesion between tumor cells and vascular endothelial cells, which eventually prevented anoikis in blood circulation [15, 20-22]. In the present study, 7a was found to inhibit the adhesion between A549 cells and HUVECs in a concentration-dependent manner. And at the same time, the expression of $\mathrm{N}$-cadherin and $\mathrm{E}$ seletin were decreased. Additionally, in the process of invasion and metastasis of tumor cells, angiogenesis of tumor cells is closely related to it. The growth and proliferation process of tumor cells is out of control and disorderly, which breaks the previous balance and needs to be supplied with sufficient oxygen and nutrients. Therefore, the formation of blood vessels plays a essential role. In an early study, a novel tumor angiogenesis modality, vasculogenic mimicry (VM), was first proposed to describe the ability of highly aggressive melanomas to dedifferentiate to acquire multiple cellular phenotypes and to acquire endothelial-like characteristics [23]. This process leads to the formation of vascular-like structures of blood vessels and red blood cells, which in turn leads to angiogenesis and the insertion of a vascular-like matrix into a network of blood vessels that promotes circulation. Subsequently, many studies found that some malignant tumors, such as breast cancer, ovarian cancer, prostate cancer, and non-small cell lung cancer, could also form mimetic blood vessels [24-26]. We found that 7a could inhibit the formation of VM by reducing the expression of VEGF. Especially in the 10 $\mu \mathrm{M}$ group, the tubular structure has almost disappeared (Fig. 4). Various studies showed that VEGF was an important pro-VM factor $[13,27]$. And VEGF was considered to promote VM by activating PI3K/Akt signaling pathway [13]. In addition to the metastasis process, 7a could also promote A549 cell apoptosis in a concentration-dependent manner. Apoptosis, a tightly regulated process of cell death, is associated with growth, organized stability, tumors, and autoimmune and neurodegenerative diseases [28]. 7a was found to reduce Bcl-2 expression, while increasing Bax, cleaved PARP and caspase-3 expression. Although Bcl-2 and Bax belong to the $\mathrm{Bcl}-2$ gene family, their exhibit an opposite effect on tumor apoptosis [29]. Bcl-2 inhibits the release of cytochrome C from mitochondria to the cytoplasm, thereby inhibiting apoptosis, while the overexpression of Bax can antagonize the protective effect of $\mathrm{Bcl}-2$ and lead to cell death [30]. Increased cytochrome $\mathrm{C}$ release in tumor cells could trigger the caspase cascade, and then PARP cleaved to cleaved PARP, which is a substrate of caspase-3 in the semicarpal protease family, eventually resulting in tumor cell apoptosis [31].

Many studies have shown that PI3K/Akt/mTOR signaling pathway plays a crucial role in the regulation of tumor growth, apoptosis, metabolism, invasion and metastasis, and angiogenesis. Therefore, the regulation of this pathway has become an interesting point in the treatment of lung cancer. The activation of PI3K/Akt signaling pathway can activate many antiapoptotic proteins, such as Bcl-2, and 
inhibit a series of proapoptotic proteins, such as Bax, caspase and p53, thereby preventing apoptotic factors from being released from mitochondria, which inhibits tumor cell apoptosis [32]. Our study found that 7a could significantly reduce the phosphorylation of some key proteins of PI3K/Akt signaling pathway, such as p-Akt, p-PI3K and p-mTOR. As discussed by Chien [33], the inhibition of PI3K/Akt signaling pathway could reduce the protein expressions of MMP-2 and MMP-9 by treating specific inhibitors for PI3K (Wortmannin). Another research reported that the inhibition of PI3K/AKT/p70S6K1 signaling pathway could significantly reduce the expression of VEGF [34]. NF-KB is a downstream signaling molecule in the PI3K/Akt signaling pathway, and its activation is closely related to a variety of pathologies, such as inflammation, adhesion, invasion, metastasis and angiogenesis [35]. NF-KB was considered to promote the formation of EMT by upregulating of E-cadherin and downregulating of $\mathrm{N}$ cadherin [36], and simultaneously upregulating MMP-2/9 [37]. Moreover, inhibition of NF-KB activity by adenovirus-mediated expression of a dominant negative NF-KB or by a proteasome inhibitor, MG132, decreased the VEGF mRNA in MDA-MB-231 cells [38]. NF-kB, as a multifunctional transcription factor, promotes gene transcription mainly by entering the nucleus. Thus, we examined the NF-KB level in the cytoplasm and nucleus separately. Our results showed that 7a markedly reduced the NF-KB level in cell nucleus, and at the same time, inhibited the phosphorylation of Akt, suggesting that 7a might inhibit A549 cell activity via PI3K/Akt/NF-KB signaling pathway.

However, we didn't conduct an in vivo experiments to validate the results in our study. Besides, we did not set a common anti-tumour drug as a control to support our observation. Therefore, further studies are still needed to verify our findings.

\section{Conclusions}

In a word, our results showed that 7a might inhibit A549 lung cancer cell proliferation, metastasis, and induce apoptosis through the PI3K/AKT/NF-KB signaling pathway. Thus, 7a may be a promising flavonoid antitumor agent for inhibiting the progression of lung cancer. And further researches are needed to investigate the detailed mechanism of $7 a$ inhibiting lung cancer.

\section{Declarations}

\section{Ethics approval and consent to participate}

Not applicable

\section{Consent for publication}

Not applicable.

\section{Availability of data and materials}

All data and materials within this study are available. 


\section{Competing interests}

The authors declare that they have no competing interests.

\section{Funding}

This work was supported by the National Natural Science Foundation of China (grant number 81903872); The Natural Science Foundation of Shandong Province (grant number ZR2020MH418).

\section{Author's contribution}

$\mathrm{JL}$ and ZQ participated in experiment design, implementation and manuscript writing. SW supplied experimental reagents. ZH consulted reference material. SH and JF helped in statistical analysis. P revised the manuscript.

\section{Acknowledgments}

The authors acknowledge the Institute of Natural Medicinal Chemistry, Qingdao University for providing the flavonoid $7 a$.

\section{References}

1. Molina JR, Yang P, Cassivi SD, et al. Non-small cell lung cancer: epidemiology, risk factors, treatment, and survivorship. Mayo Clin Proc 2008;83:584-94. https://doi.org/10.4065/83.5.584

2. Torre LA, Bray F, Siegel RL, et al. Global cancer statistics, 2012. CA Cancer J Clin 2015;65:87-108. https://doi.org/10.3322/caac.21262

3. Quint LE, Tummala S, Brisson LJ, et al. Distribution of distant metastases from newly diagnosed non-small cell lung cancer. Ann Thorac Surg 1996;62:246-50. https://doi.org/10.1016/00034975(96)00220-2

4. Vaya J, Belinky PA, Aviram M. Antioxidant constituents from licorice roots: isolation, structure elucidation and antioxidative capacity toward LDL oxidation. Free Radic Biol Med 1997;23:302-13. https://doi.org/10.1016/s0891-5849(97)00089-0

5. Chan SC, Chang YS, Wang JP, et al. Three new flavonoids and antiallergic, anti-inflammatory constituents from the heartwood of Dalbergia odorifera. Planta Med 1998;64:153-8. https://doi.org/10.1055/s-2006-957394

6. Yamamoto $\mathrm{S}$, Aizu $\mathrm{E}$, Jiang $\mathrm{H}$, et al. The potent antitumor-promoting agent isoliquiritigenin. Carcinogenesis 1991;12:317-23. https://doi.org/10.1093/carcin/12.2.317

7. Cuendet M, Guo J, Luo Y, et al. Cancer chemopreventive activity and metabolism of isoliquiritigenin, a compound found in licorice. Cancer Prev Res (Phila) 2010;3:221-32. https://doi.org/10.1158/19406207.CAPR-09-0049 
8. Tian T, Sun J, Wang J, et al. Isoliquiritigenin inhibits cell proliferation and migration through the PI3K/AKT signaling pathway in A549 lung cancer cells. Oncol Lett 2018;16:6133-9. https://doi.org/10.3892/ol.2018.9344

9. Liang CC, Park AY, Guan JL. In vitro scratch assay: a convenient and inexpensive method for analysis of cell migration in vitro. Nat Protoc 2007;2:329-33. https://doi.org/10.1038/nprot.2007.30

10. Yu LG, Andrews N, Zhao Q, et al. Galectin-3 interaction with Thomsen-Friedenreich disaccharide on cancer-associated MUC1 causes increased cancer cell endothelial adhesion. J Biol Chem 2007;282:773-81. https://doi.org/10.1074/jbc.M606862200

11. Herzig M, Savarese F, Novatchkova M, et al. Tumor progression induced by the loss of E-cadherin independent of beta-catenin/Tcf-mediated Wnt signaling. Oncogene 2007;26:2290-8. https://doi.org/10.1038/sj.onc.1210029

12. Passalidou $\mathrm{E}$, Trivella $\mathrm{M}$, Singh $\mathrm{N}$, et al. Vascular phenotype in angiogenic and non-angiogenic lung non-small cell carcinomas. Br J Cancer 2002;86:244-9. https://doi.org/10.1038/sj.bjc.6600015

13. Xu X, Zong Y, Gao Y, et al. VEGF induce vasculogenic mimicry of choroidal melanoma through the PI3k signal pathway. Biomed Res Int 2019;2019:3909102. https://doi.org/10.1155/2019/3909102

14. Cao Z, Hao Z, Xin M, et al. Endogenous and exogenous galectin-3 promote the adhesion of tumor cells with low expression of MUC1 to HUVECs through upregulation of N-cadherin and CD44. Lab Invest 2018;98:1642-56. https://doi.org/10.1038/s41374-018-0119-3

15. Xu G, Zhang W, Bertram P, et al. Pharmacogenomic profiling of the PI3K/PTEN-AKT-mTOR pathway in common human tumors. Int J Oncol 2004;24:893-900. https://doi.org/10.3892/ijo.24.4.893

16. Jung SK, Lee MH, Lim DY, et al. Isoliquiritigenin induces apoptosis and inhibits xenograft tumor growth of human lung cancer cells by targeting both wild type and L858R/T790M mutant EGFR. $J$ Biol Chem 2014;289:35839-48. https://doi.org/10.1074/jbc.M114.585513

17. Nakajima S, Doi R, Toyoda E, et al. N-cadherin expression and epithelial-mesenchymal transition in pancreatic carcinoma. Clin Cancer Res 2004;10:4125-33. https://doi.org/10.1158/1078-0432.CCR0578-03

18. Merchant N, Nagaraju GP, Rajitha B, et al. Matrix metalloproteinases: their functional role in lung cancer. Carcinogenesis 2017;38:766-80. https://doi.org/10.1093/carcin/bgx063

19. Brown GT, Murray GI. Current mechanistic insights into the roles of matrix metalloproteinases in tumour invasion and metastasis. J Patho/2015;237:273-81. https://doi.org/10.1002/path.4586

20. Makrilia N, Kollias A, Manolopoulos L, et al. Cell adhesion molecules: role and clinical significance in cancer. Cancer Invest 2009;27:1023-37. https://doi.org/10.3109/07357900902769749

21. Zhao Q, Barclay M, Hilkens J, et al. Interaction between circulating galectin-3 and cancer-associated MUC1 enhances tumour cell homotypic aggregation and prevents anoikis. Mol Cancer 2010;9:154. https://doi.org/10.1186/1476-4598-9-154

22. Zhao Q, Guo X, Nash GB, et al. Circulating galectin-3 promotes metastasis by modifying MUC1 localization on cancer cell surface. Cancer Res 2009;69:6799-806. https://doi.org/10.1158/00085472.CAN-09-1096 
23. Maniotis AJ, Folberg R, Hess A, et al. Vascular channel formation by human melanoma cells in vivo and in vitro: vasculogenic mimicry. Am J Patho/ 1999;155:739-52. https://doi.org/10.1016/S00029440(10)65173-5

24. Shirakawa $\mathrm{K}$, Tsuda $\mathrm{H}$, Heike $\mathrm{Y}$, et al. Absence of endothelial cells, central necrosis, and fibrosis are associated with aggressive inflammatory breast cancer. Cancer Res 2001;61:445-51. https://doi.org/10.1016/S0165-4608(00)00343-5

25. Sood AK, Seftor EA, Fletcher MS, et al. Molecular determinants of ovarian cancer plasticity. Am J Pathol 2001;158:1279-88. https://doi.org/10.1016/S0002-9440(10)64079-5

26. Sharma N, Seftor RE, Seftor EA, et al. Prostatic tumor cell plasticity involves cooperative interactions of distinct phenotypic subpopulations: role in vasculogenic mimicry. Prostate 2002;50:189-201. https://doi.org/10.1002/pros.10048

27. Mei J, Gao Y, Zhang L, et al. VEGF-siRNA silencing induces apoptosis, inhibits proliferation and suppresses vasculogenic mimicry in osteosarcoma in vitro. Exp Oncol 2008;30:29-34.

28. Meier P, Finch A, Evan G. Apoptosis in development. Nature 2000;407:796-801. https://doi.org/10.1038/35037734

29. Brown R. The bcl-2 family of proteins. Br Med Bull 1997;53:466-77. https://doi.org/10.1001/archfami.6.1.79

30. Knight T, Luedtke D, Edwards $\mathrm{H}$, et al. A delicate balance-The BCL-2 family and its role in apoptosis, oncogenesis, and cancer therapeutics. Biochem Pharmacol 2019;162:250-61. https://doi.org/10.1016/j.bcp.2019.01.015

31. Breckenridge $D G$, Xue $D$. Regulation of mitochondrial membrane permeabilization by BCL-2 family proteins and caspases. Curr Opin Cell Biol 2004;16:647-52.

https://doi.org/10.1016/j.ceb.2004.09.009

32. Seo BR, Min KJ, Cho IJ, et al. Curcumin significantly enhances dual PI3K/Akt and mTOR inhibitor NVP-BEZ235-induced apoptosis in human renal carcinoma Caki cells through down-regulation of p53-dependent Bcl-2 expression and inhibition of Mcl-1 protein stability. PLoS One 2014;9:e95588. https://doi.org/10.1371/journal.pone.0095588

33. Chien CS, Shen $\mathrm{KH}$, Huang JS, et al. Antimetastatic potential of fisetin involves inactivation of the $\mathrm{PI} 3 \mathrm{~K} / \mathrm{Akt}$ and JNK signaling pathways with downregulation of MMP-2/9 expressions in prostate cancer PC-3 cells. Mol Cell Biochem 2010;333:169-80. https://doi.org/10.1007/s11010-009-0217-z

34. Zhong XS, Zheng JZ, Reed E, et al. SU5416 inhibited VEGF and HIF-1alpha expression through the PI3K/AKT/p70S6K1 signaling pathway. Biochem Biophys Res Commun 2004;324:471-80. https://doi.org/10.1016/j.bbrc.2004.09.082

35. Aggarwal BB. Nuclear factor-kappaB: the enemy within. Cancer Cell 2004;6:203-8. https://doi.org/10.1016/j.ccr.2004.09.003

36. Zhou P, Wang C, Hu Z, et al. Genistein induces apoptosis of colon cancer cells by reversal of epithelial-to-mesenchymal via a Notch1/NF-kappaB/slug/E-cadherin pathway. BMC Cancer 2017;17:813. https://doi.org/10.1186/s12885-017-3829-9

Page 14/21 
37. Li J, Lau GK, Chen L, et al. Interleukin 17A promotes hepatocellular carcinoma metastasis via NF-kB induced matrix metalloproteinases 2 and 9 expression. PLoS One 2011;6:e21816.

https://doi.org/10.1371/journal.pone.0021816

38. Shibata A, Nagaya T, Imai T, et al. Inhibition of NF-kappaB activity decreases the VEGF mRNA expression in MDA-MB-231 breast cancer cells. Breast Cancer Res Treat 2002;73:237-43. https://doi.org/10.1023/a:1015872531675

Figures

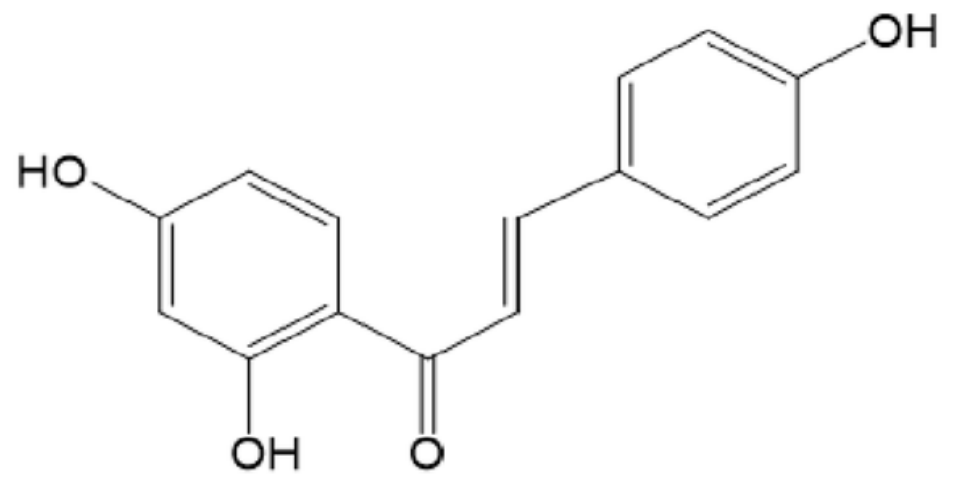

ISL

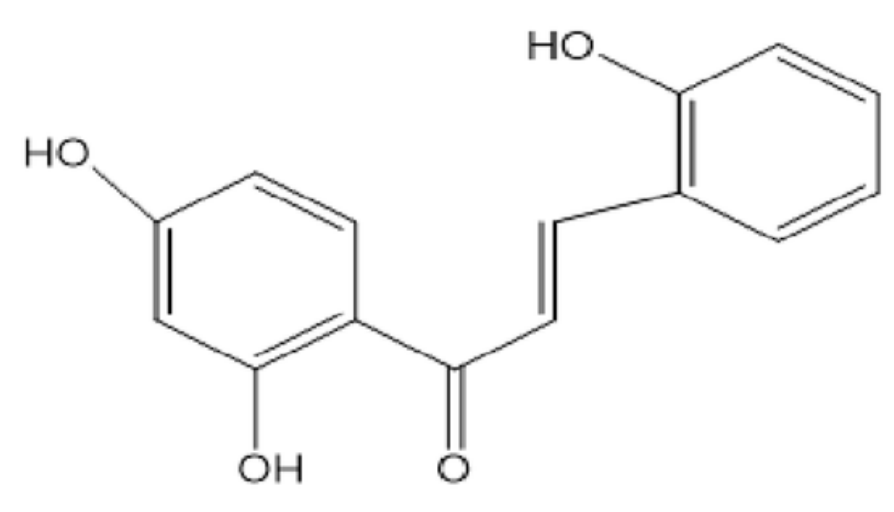

$7 \mathbf{a}$

Figure 1

The chemical structure of ISL and 7a

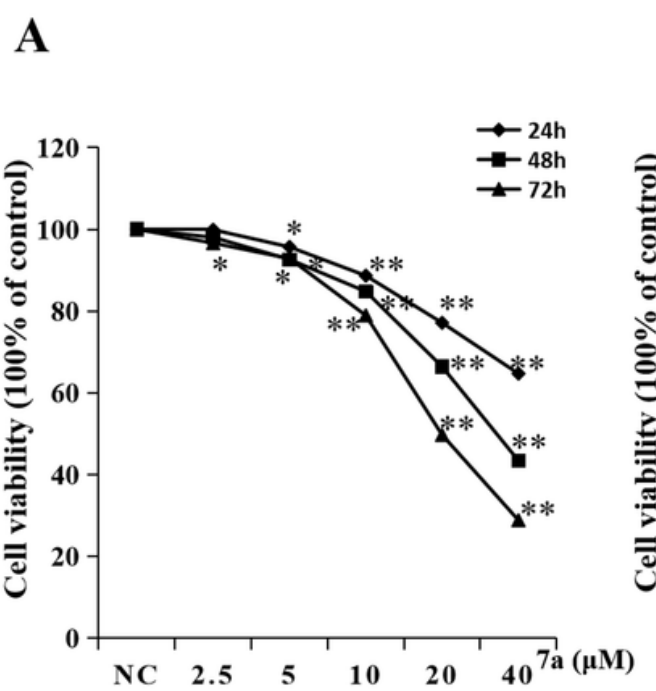

A549
B C

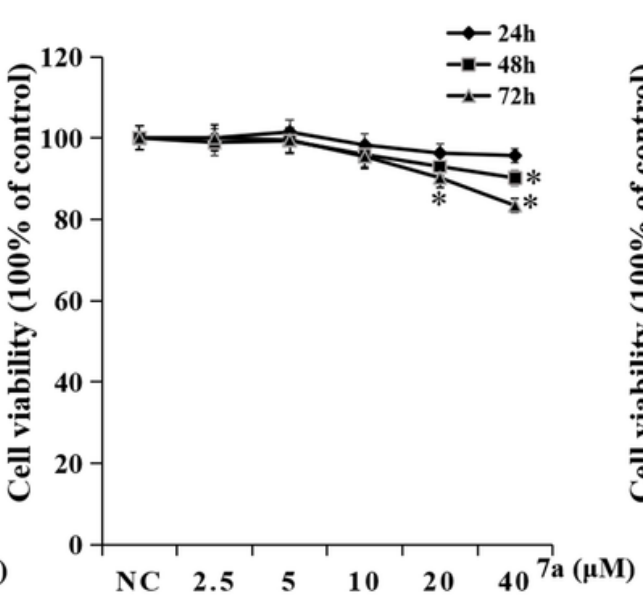

HUVEC

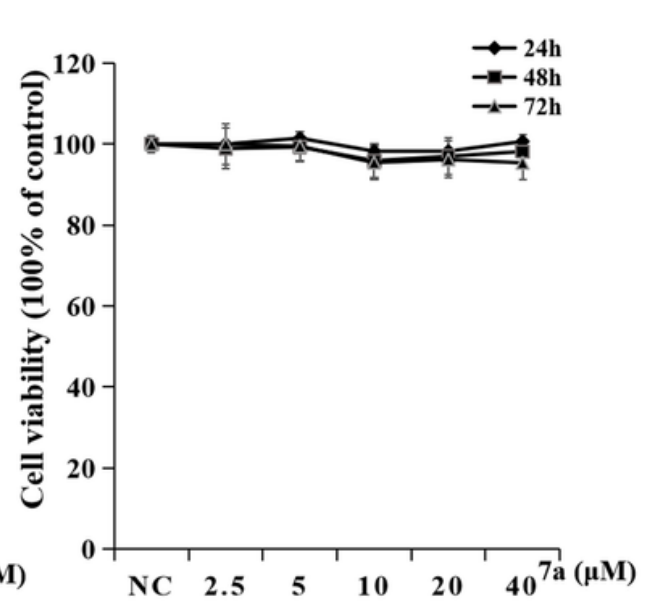

BEAS-2B

Figure 2 
Inhibitory effects of 7a on the proliferation of A549 (A), HUVEC (B), and BEAS-2B cells (C) were measured by CCK-8 assay after incubated with various concentrations of $7 \mathrm{a}$ for $24,48,72 \mathrm{~h}$, respectively. Data are presented as the means \pm standard deviation of three separate experiments. ${ }^{*} P<0.05$ and ${ }^{* *} P<0.01$ compared with NC. NC, negative control.
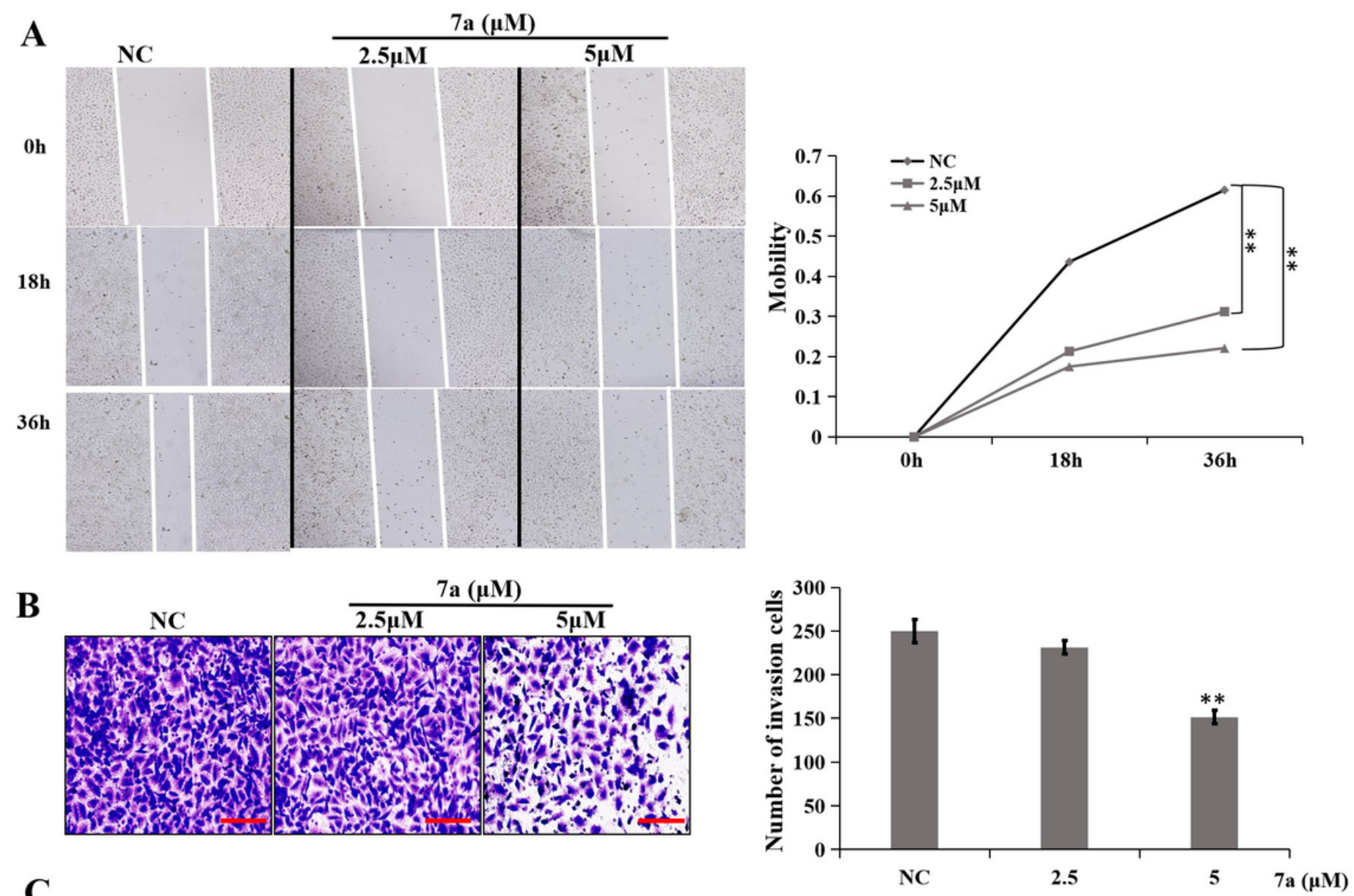

C
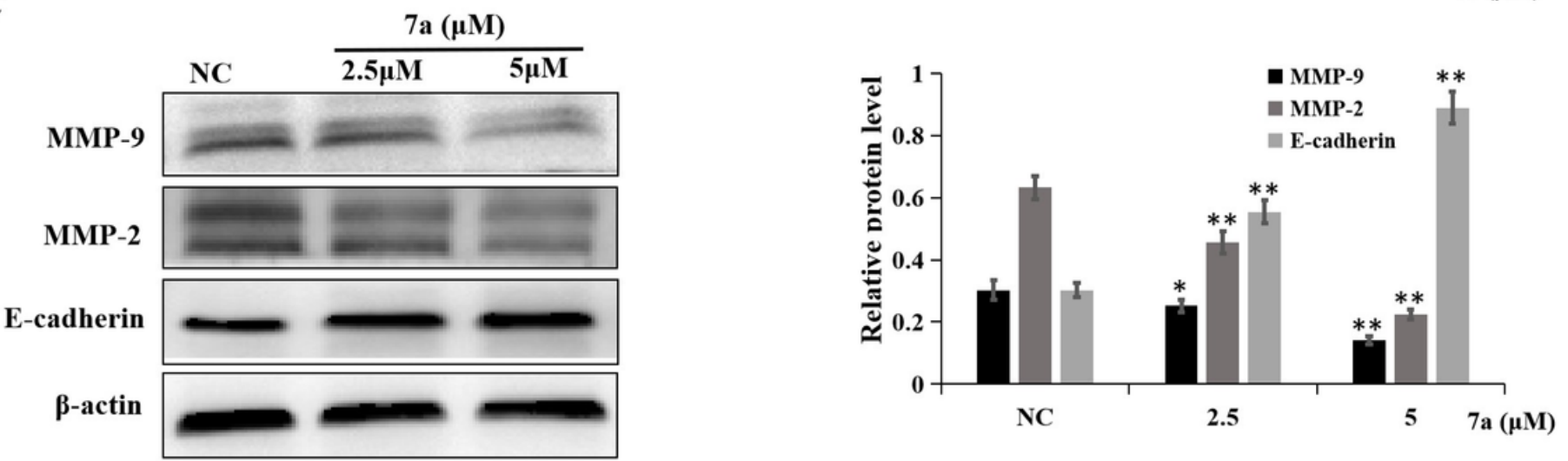

Figure 3

The non-cytotoxic concentrations of 7a on the migration and invasion of A549 cells after treated with different 7a. A: Wound healing assay was performed to detect the migration of A549 cells after treatment with $7 \mathrm{a}$ for 0,18 , and $36 \mathrm{~h}$. B: A549 cells treated with different concentrations of $7 \mathrm{a}$ were placed on the filters with Matrigel and incubated for $24 \mathrm{~h}(\mathrm{bar}=50 \mu \mathrm{m})$. C: The expression of MMP-2/9 and E-cadherin in A549 cells after treatment with different concentrations of $7 \mathrm{a}$ for $24 \mathrm{~h}$ were measured by western blot 
analysis. Data are presented as the means \pm SD from three separate experiments. ${ }^{*} \mathrm{P}<0.05$ and ${ }^{\star *} \mathrm{P}<$ 0.01 compared with NC. NC, negative control.

A
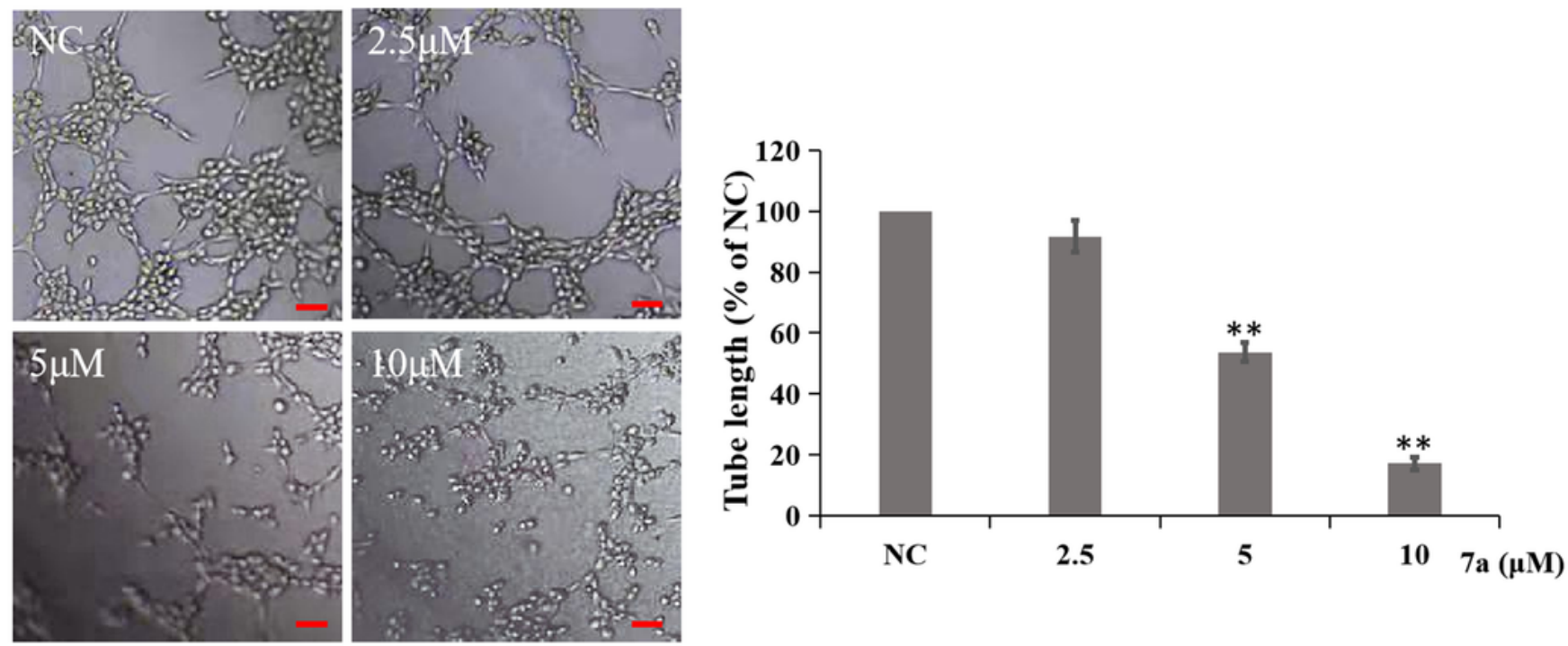

B

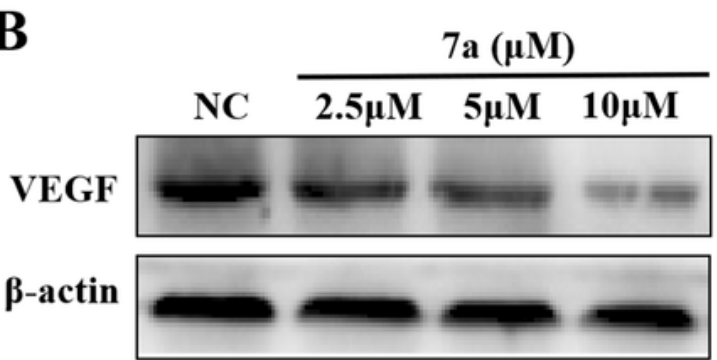

C

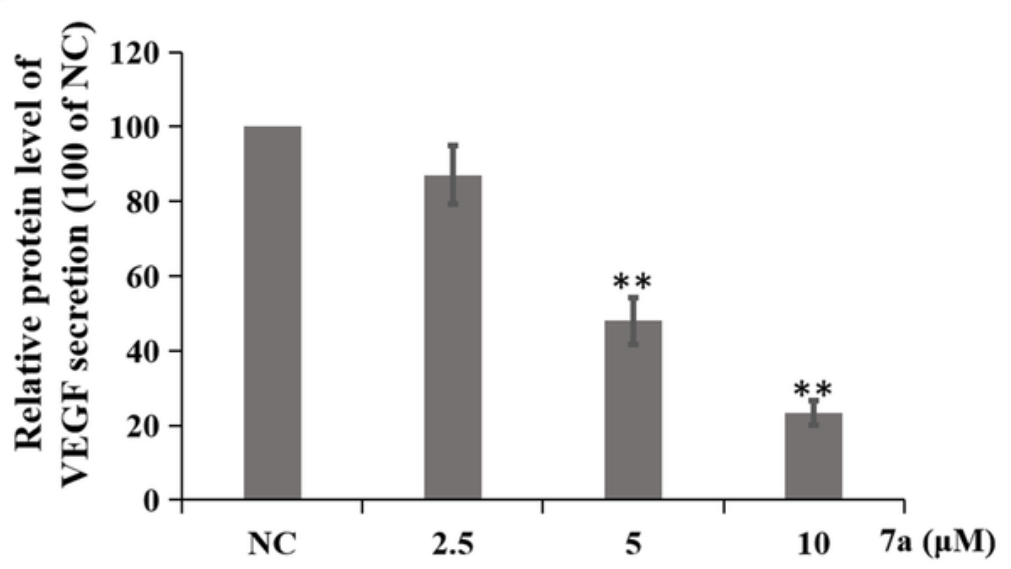

Figure 4

Inhibitory effect of 7a on the VM formation of A549 cells. A: 7a suppressed VM formation of A549 cells in vitro. Representative images of VM formation after treatment with different concentrations of $7 \mathrm{a}$ for $8 \mathrm{~h}$

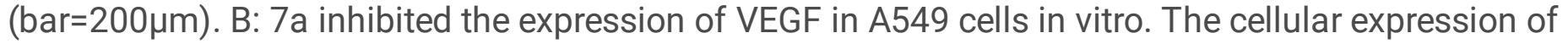


VEGF in A549 cells after treatment with different concentrations of $7 \mathrm{a}$ for $24 \mathrm{~h}$ were measured by western blot analysis. C: Secretion of VEGF in A549 cell culture medium treated with 7a for $24 \mathrm{~h}$ was examined by ELISA assay. Data are presented as the means \pm SD from three separate experiments. ${ }^{*} \mathrm{P}<0.05$ and ${ }^{* *} \mathrm{P}<$ 0.01 compared with NC. NC, negative control.

A
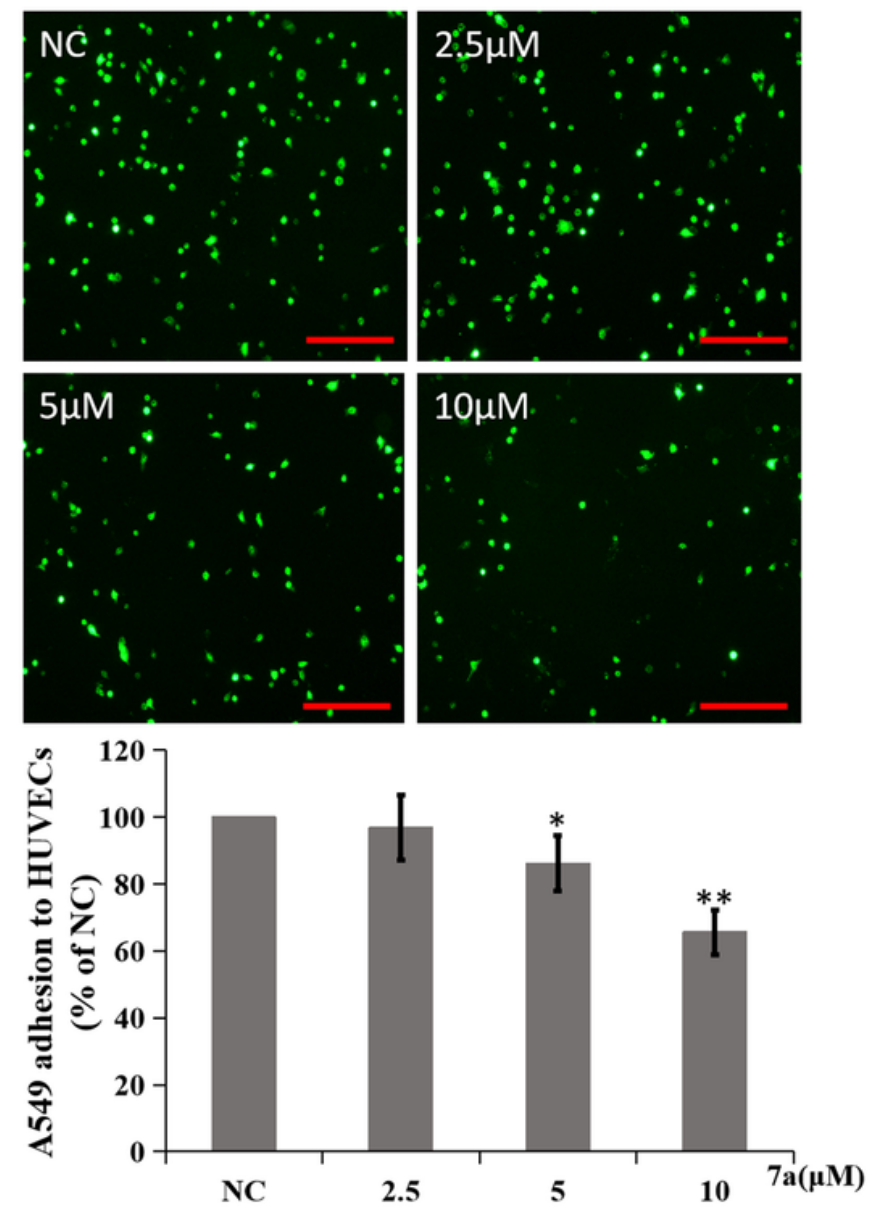

\section{B}
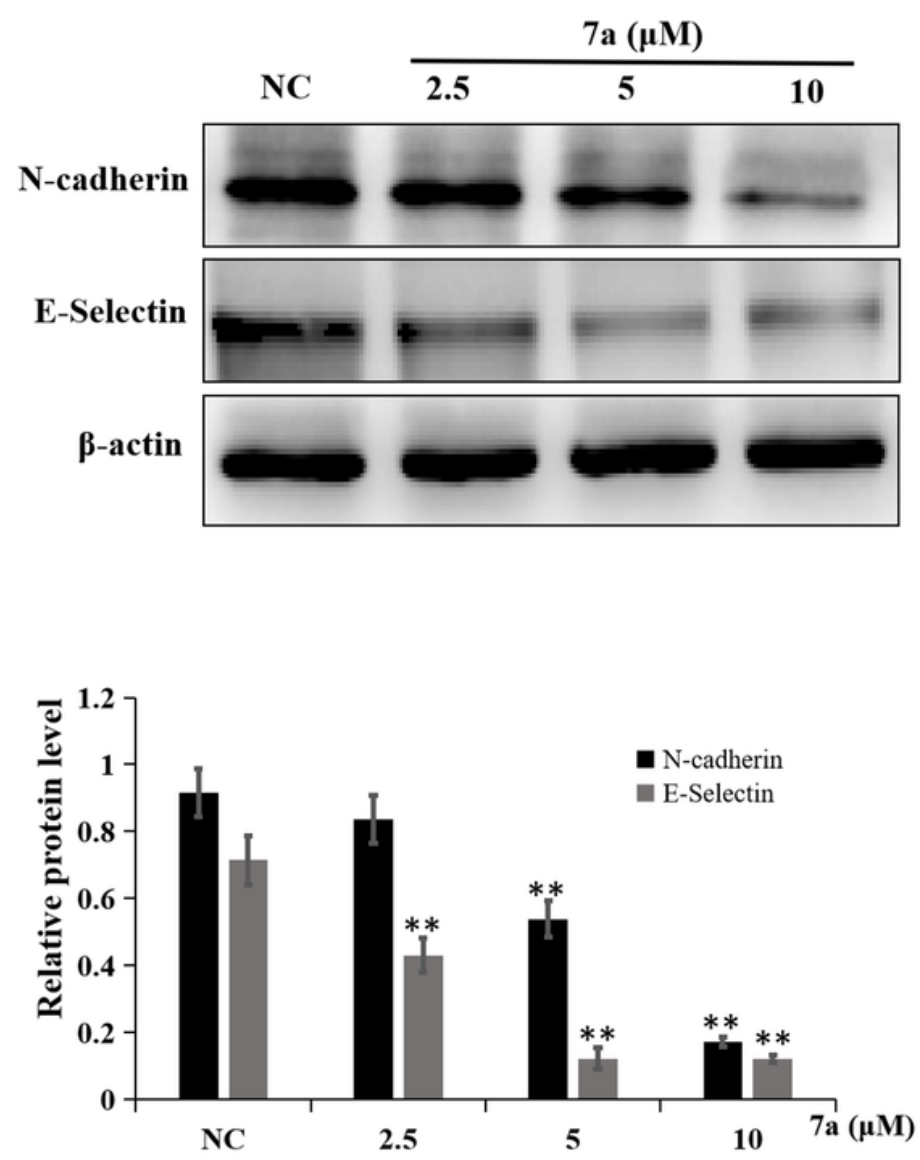

\section{Figure 5}

Inhibitory effect of 7a on the ability of A549 cell adhesion to monolayer HUVEC cells. A: The fluorescentlabeled cells were counted between five and ten randomly chosen low power fields under a fluorescent microscope (bar $=100 \mu \mathrm{m})$. B: Expression of $\mathrm{N}$-cadherin and E-Selectin in A549 cells following 7a treatment for $48 \mathrm{~h}$ was determined by using western blot analysis. Data are presented as the means $\pm \mathrm{SD}$ from three separate experiments. ${ }^{*} P<0.05$ and ${ }^{*}{ }^{*}<<0.01$ compared with NC. NC, negative control. 
A

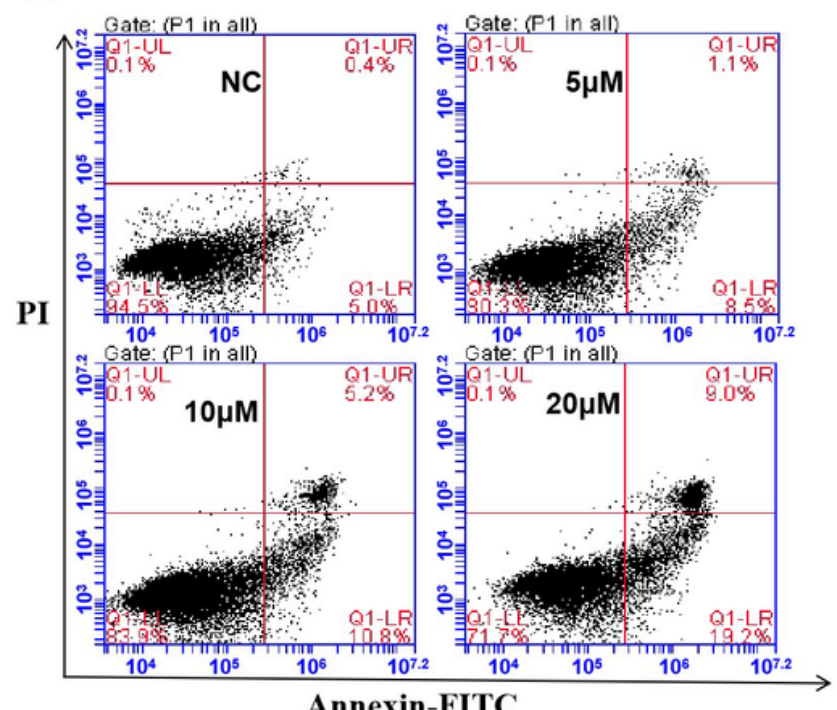

Annexin-FITC

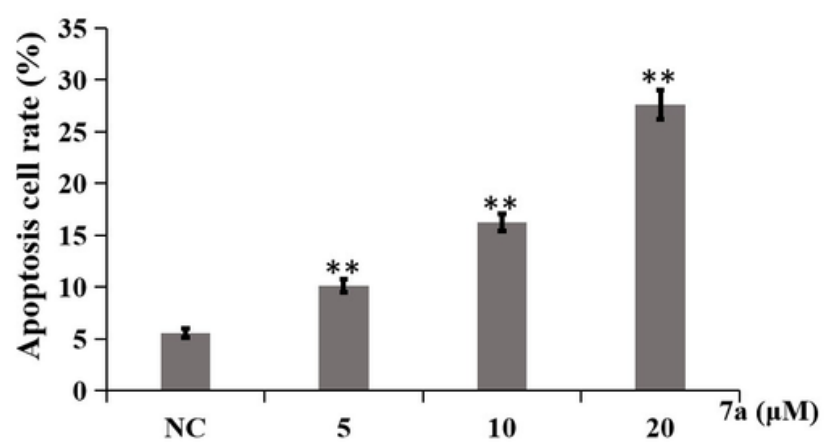

B
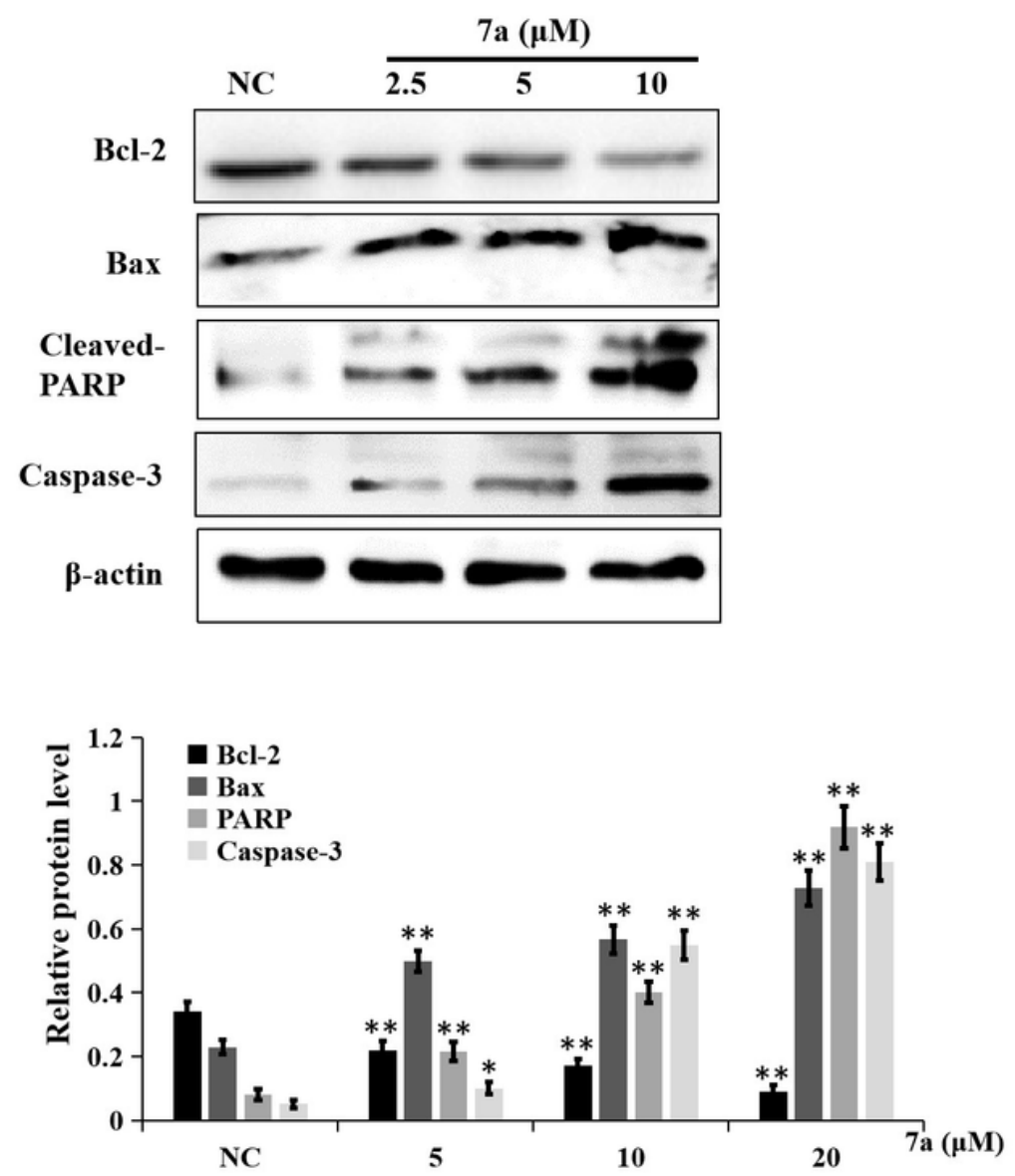

Figure 6

$7 \mathrm{a}$ induces apoptosis of A549 cells via the mitochondrial apoptosis pathway. A: Detection of apoptotic cells after Annexin V/PI by flow cytometry analysis after A549 cells treated with different concentrations of 7a for 48h. Q1-LL, LR, UR, and UL, respectively, represent normal cells, early apoptotic cells, late apoptotic cells, and necrotic cells. The percentages of apoptotic cells (both early and late) were scored in three separate experiments. B: The expression of four apoptosis-related proteins in A549 cells following $7 \mathrm{a}$ treatment for $48 \mathrm{~h}$ was measured by using western blot analysis. The semiquantitative expression levels of the proteins were carried out according to the exposure gray value. Data are presented as the means \pm SD from three separate experiments. ${ }^{*} \mathrm{P}<0.05$ and ${ }^{*} \mathrm{P}<0.01$ compared with $\mathrm{NC}$. NC, negative control. 
A
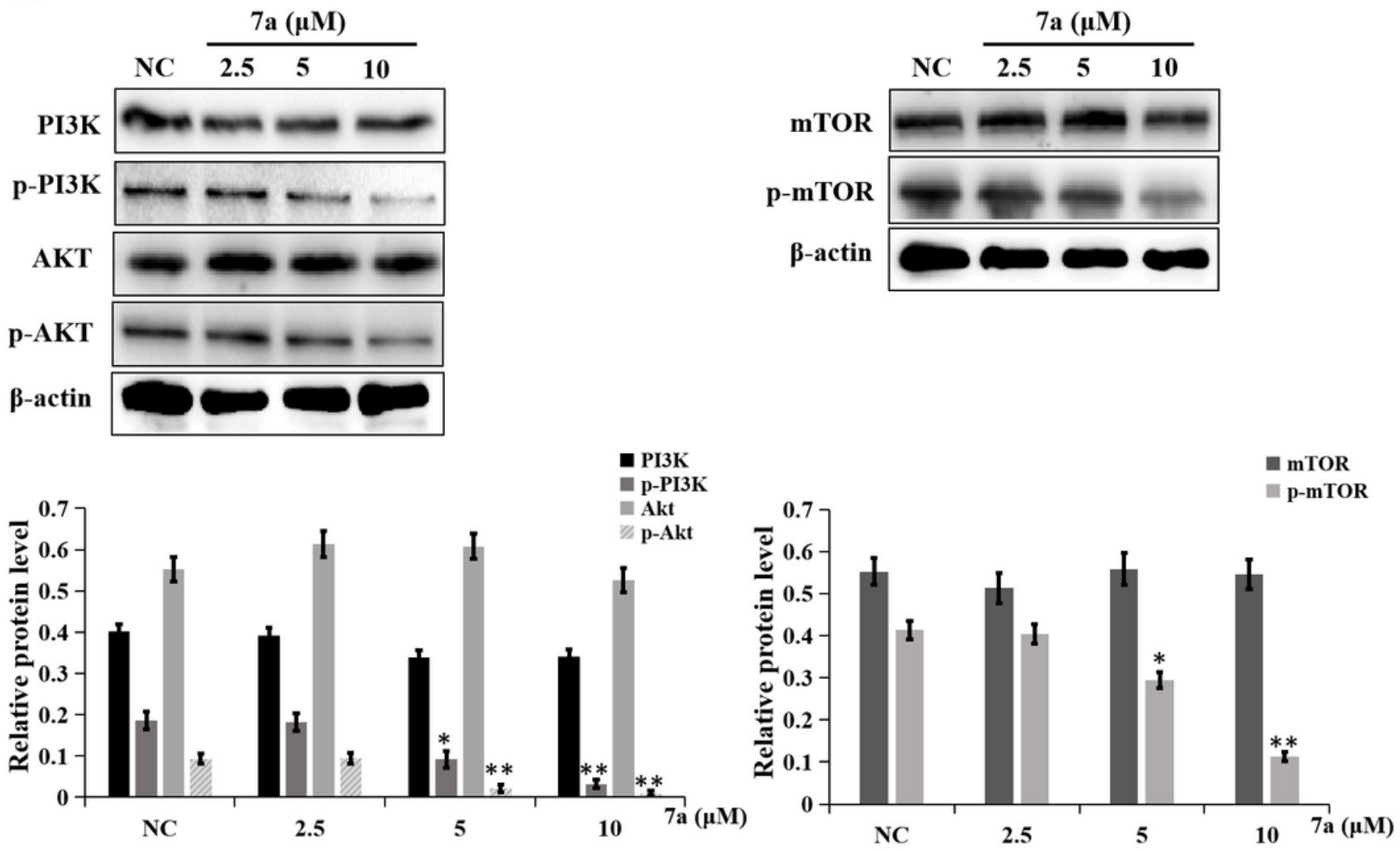

B
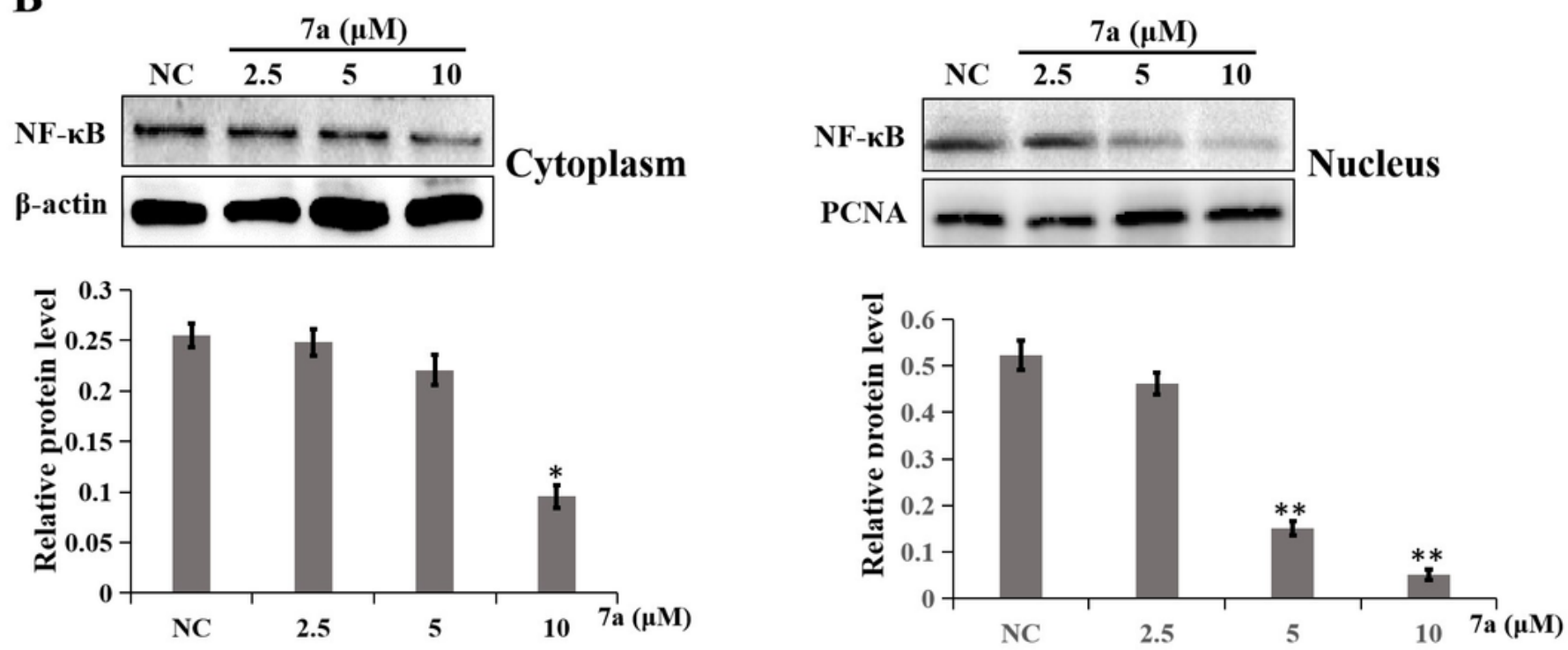

\section{Figure 7}

7a inhibits the activation of the PI3K/AKT/NF-KB signaling pathway in A549 cells. A: Effects of 7a on the expression of PI3K, p-PI3K, AKT, p-AKT, mTOR, and p-mTOR in A549 cells were detected by western blot. $\mathrm{B}$ : Cytoplasmic and nuclear NF-KB was detected separately by using western blot analysis. $\beta$-actin and PCNA were used as the loading control in the cytoplasm and nucleus, respectively. Data are presented as 
the means \pm SD from three separate experiments. ${ }^{*} P<0.05$ and ${ }^{* * P}<0.01$ compared with NC. NC, negative control. 